\title{
A small compound spindlactone $A$ sensitizes human endometrial cancer cells to TRAIL-induced apoptosis via the inhibition of NAD(P)H dehydrogenase quinone I [Corrigendum]
}

\author{
Zhao XZ, Wu XH. Onco Targets Ther. 2018;11:3609-3617. \\ On page 3609, affiliation 2 should read as follows: \\ ${ }^{2}$ Department of Gynecology and Obstetrics, Hebei Medical \\ University, Hebei 050017, People's Republic of China \\ On page 3609 , the correspondence details should read as \\ follows: \\ Correspondence: Xiao-Hua Wu \\ Department of Gynecology and Obstetrics, Hebei Medical \\ University, No 361 East Zhongshan Road, Shijiazhuang, \\ Hebei, 050017, People's Republic of China \\ $\mathrm{Tel} / \mathrm{fax}+8631187023626$ \\ Email1466974429@qq.com
}

OncoTargets and Therapy is an international, peer-reviewed, open access journal focusing on the pathological basis of all cancers, potential targets for therapy and treatment protocols employed to improve the management of cancer patients. The journal also focuses on the impact of management programs and new therapeutic agents and protocols on

patient perspectives such as quality of life, adherence and satisfaction. The manuscript management system is completely online and includes a very quick and fair peer-review system, which is all easy to use. Visit http://www.dovepress.com/testimonials.php to read real quotes from published authors. 